(2) Open Access Full Text Article

\title{
Atomoxetine affects transcription/translation of the NMDA receptor and the norepinephrine transporter in the rat brain - an in vivo study
}

This article was published in the following Dove Press journal:

Drug Design, Development and Therapy

3 December 2013

Number of times this article has been viewed

\section{Patrick T Udvardi ${ }^{1,2}$ \\ Karl J Föhr ${ }^{3}$ \\ Carolin Henes ${ }^{1,2}$ \\ Stefan Liebau ${ }^{2}$ \\ Jens Dreyhaupt ${ }^{4}$ \\ Tobias M Boeckers ${ }^{2}$ \\ Andrea G Ludolph'}

'Department of Child and Adolescent Psychiatry and Psychotherapy, ${ }^{2}$ Institute of Anatomy and Cell Biology, ${ }^{3}$ Department of Anaesthesiology,

${ }^{4}$ Institute of Epidemiology and Medical Biometry, University of Ulm, Ulm, Germany
Correspondence: Andrea G Ludolph Department of Child and Adolescent Psychiatry and Psychotherapy,

University of Ulm, Steinhoevelstr 5, D-89075 Ulm, Germany

$\mathrm{Tel}+4973150061601$

Fax +49 73I 50061662

Email andrea.ludolph@uni-ulm.de
Abstract: Attention-deficit/hyperactivity disorder (ADHD) is the most frequently diagnosed neurodevelopmental disorder. The norepinephrine transporter (NET) inhibitor atomoxetine, the first nonstimulant drug licensed for ADHD treatment, also acts as an $N$-methyl- $D$-aspartate receptor (NMDAR) antagonist. The compound's effects on gene expression and protein levels of NET and NMDAR subunits (1,2A, and 2B) are unknown. Therefore, adolescent Sprague Dawley rats were treated with atomoxetine $(3 \mathrm{mg} / \mathrm{kg}$, intraperitoneal injection [ip]) or saline $(0.9 \%$, ip) for 21 consecutive days on postnatal days (PND) 21-41. In humans, atomoxetine's earliest clinical therapeutic effects emerge after 2-3 weeks. Material from prefrontal cortex, striatum (STR), mesencephalon (MES), and hippocampus (HC) was analyzed either directly after treatment (PND 42) or 2 months after termination of treatment (PND 101) to assess the compound's long-term effects. In rat brains analyzed immediately after treatment, protein analysis exhibited decreased levels of the NET in HC, and NMDAR subunit $2 \mathrm{~B}$ in both STR and $\mathrm{HC}$; the transcript levels were unaltered. In rat brains probed 2 months after final atomoxetine exposure, messenger RNA analysis also revealed significantly reduced levels of genes coding for NMDAR subunits in MES and STR. NMDAR protein levels were reduced in STR and HC. Furthermore, the levels of two SNARE (soluble N-ethylmaleimide-sensitive factor attachment protein receptor) proteins, synaptophysin and synaptosomal-associated protein 25 , were also significantly altered in both treatment groups. This in vivo study detected atomoxetine's effects beyond NET inhibition. Taken together, these data reveal that atomoxetine seems to decrease glutamatergic transmission in a brain region-specific manner. Long-term data show that the compound's impact is not due to an acute pharmacological effect but lasts or even amplifies after a drug-free period of 2 months, leading to altered development of synaptic composition. These alterations might contribute to atomoxetine's clinical effects in the treatment of ADHD, a neurodevelopmental disorder in which synaptic processes and especially a dysregulated glutamatergic metabolism seem to be involved.

Keywords: attention-deficit hyperactivity disorder (ADHD), neurodevelopment, atomoxetine, in vivo study, altered gene expression, $N$-methyl- $D$-aspartate receptor

\section{Introduction}

The pathogenesis of attention-deficit/hyperactivity disorder (ADHD), the most frequently diagnosed neuropsychiatric disorder in childhood with a prevalence of $5 \%-6 \%,{ }^{1}$ and the mechanisms of its psychopharmacological treatments are still far from being completely understood. Distinctly increased hyperactivity, pronounced inattention, and impulsivity not appropriate for age are the three cardinal symptoms of ADHD. ${ }^{2,3}$ ADHD often persists into adulthood; $1 \%-4 \%$ of adults seem to remain affected. ${ }^{4}$ It 
is hypothesized that dysfunctional norepinephrinergic (NE) and dopaminergic signal processing within various brain areas, especially in the cortico-striatal-thalamic-cortical loop, give rise to an imbalanced state of arousal. This, in consequence, presumably leads to the noted ADHD symptoms. ${ }^{5}$ To date, psychostimulants such as methylphenidate or amphetamine salts represent the first-line treatment to attenuate ADHD core symptoms. ${ }^{6}$ Nonetheless, about $10 \%-20 \%$ of the patients show only limited benefit from stimulants, ${ }^{7}$ whose major effects seem to depend on the inhibition of the striatal presynaptic dopamine transporter., ${ }^{8,9}$

A growing body of evidence indicates that alterations of the monoaminergic system alone are not the only primary pathophysiological cause for ADHD symptoms; dysfunctions of the glutamatergic neurotransmitter system also seem to play a major role in the pathophysiology of ADHD. ${ }^{10,11}$ Glutamate is the main excitatory neurotransmitter in the mammalian brain, and over $60 \%$ of all synapses are glutamatergic. ${ }^{12}$ The glutamate receptors include the G-protein-coupled metabotropic glutamate receptors and the ionotropic cation-permeable receptor-channels: the kainate receptors, the AMPAR ( $\alpha$-amino-3-hydroxy-5-methyl4-isoxazolepropionic acid receptors), and the NMDAR ( $N$-methyl- $D$-aspartate receptors) with seven different subunits: NR1, NR2A-D and NR3A, and B. ${ }^{13}$ The receptor subunits and their isoforms have unique biophysical properties and display a defined regional and developmental expression pattern. The NR2 subunits play a crucial role during brain development, controlling synaptic plasticity and memory function. ${ }^{14}$ In the rat brain, NR2B-containing receptors contribute to long-term potentiation (LTP) during adolescence, whereas NR1/NR2A receptors mediate LTP in adults. ${ }^{15}$ Grin $2 B$ (NR2B) is predominantly expressed during early developmental stages, and its expression is downregulated around the third postnatal week, whereas the subunit NR2A first appears around birth, dramatically increases thereafter, and peaks 3 weeks after birth. ${ }^{16}$ NMDARs are not limited to the postsynaptic membrane. They were also identified at extra-, peri-, and presynaptic sites, ${ }^{17-20}$ where they display diverse physiological roles, eg, signaling through extrasynaptic NMDARs, which mainly contain the NR2B subunit, have inhibitory effects. ${ }^{21}$ Recently, dysfunctions of the NMDARs have been linked to ADHD. ${ }^{22}$ LTP is strongly mediated by the NMDARs containing the subunit $2 \mathrm{~A}$. The spontaneously hypertensive rat (SHR), the best-characterized ADHD animal model, produces NMDARs more frequently containing NR2B than NR2A. ${ }^{22}$ Consequently, AMPAR insertion into the postsynaptic membrane is suppressed, which reduces LTP and synaptic plasticity. ${ }^{23,24}$ Although glutamate has a predominant role in synaptic plasticity, learning and memory, pathological concentrations are highly excitotoxic and lead to neuronal cell death. ${ }^{12}$ Lou, in a 1996 study, already linked excessive glutamate release in the striatum (STR) to the onset of ADHD. ${ }^{25}$

Atomoxetine, a selective NE transporter (NET) antagonist, ${ }^{26-28}$ is the first nonstimulant compound licensed for the treatment of ADHD in children, adolescents, and adults. ${ }^{29}$ Current knowledge about atomoxetine's cellular mechanisms of action is still limited. After oral application, increased intrasynaptic NE levels are detectable within hours in the nonhuman primate brain as shown by positron emission tomography (PET) with (S,S)-[18F] FMeNER-D2, a ligand to the NET. ${ }^{30}$ A second PET study with the same ligand indicates that NET is occupied within 15 minutes after intravenous application of atomoxetine at intracerebral concentrations as low as $16 \mathrm{ng} / \mathrm{mL}$ measured in the thalamus. The authors conclude that clinical doses of atomoxetine occupy NET almost completely within 15 minutes. ${ }^{31}$ Atomoxetine's earliest therapeutic effects, however, only occur after $2-3$ weeks of treatment. ${ }^{32}$ Therefore, it seems to be very unlikely that the therapeutic effects are solely due to the NET inhibition. In addition, the recommended therapeutic plasma level is 200-1,000 ng/mL, ${ }^{33}$ a concentration presumably leading to much higher brain levels than measured in the above mentioned PET study. ${ }^{34}$

Few in vivo or in vitro studies have been conducted to investigate atomoxetine's cellular and neurochemical effects. ${ }^{35-37}$ Furthermore, until now no study has characterized its long-term biological effects. The aim of the present study was to ascertain atomoxetine's further cellular action beyond the inhibition of NET. Previously, we could show that atomoxetine acts as an NMDAR antagonist in clinically relevant doses in vitro. ${ }^{38}$ Therefore, in the present study, we addressed the issue of whether atomoxetine also alters transcript and protein levels of the NMDAR subunits (NR1, NR2A, and NR2B) and NET. Additionally, we analyzed immediate and long-term effects of atomoxetine on the expression and protein levels of the mentioned NMDAR subunits and NET in the male adolescent brain.

Prefrontal cortex (PFC) and STR, as part of the corticostriatal-thalamic-cortical circuit, and mesencephalon (MES) and hippocampus (HC), as parts of the limbic system and crucial for learning and memory, ${ }^{22}$ were investigated separately. Doing so allowed us to detect possible brain regionspecific effects. 


\section{Materials and methods}

\section{Animal housing}

Crl:CD(SD) rats (Charles River Laboratories:Cesarean derived [Sprague Dawley]) for breeding were obtained from Charles River Laboratories (Wilmington, MA, USA) and housed in groups of two under controlled temperature $\left(21^{\circ} \mathrm{C} \pm 2^{\circ} \mathrm{C}\right)$, humidity $(60 \%-65 \%)$, and a $12: 12$ hour lightdark cycle. Food and water were available ad libitum. Pregnant rats were housed separately, and pups were separated from the dams at postnatal day (PND) 21.

\section{Treatment procedures}

Male adolescent rats were treated from PND 21-42 and either analyzed immediately or housed for another 2 months off-drug and analyzed thereafter. The two groups were named "early treatment group" and "late treatment group", respectively.

Atomoxetine hydrochloride (Sigma-Aldrich, St Louis, MO, USA) was dissolved in $0.9 \%$ saline (Fresenius Kabi AG, Bad Homburg, Germany) and was administered by intraperitoneal (ip) injection into rats $(\mathrm{n}=7-8)$ at a dose of $3 \mathrm{mg} / \mathrm{kg}$ daily dose. Control animals $(\mathrm{n}=7-8)$ were agematched to atomoxetine treated rats (PND 21 days) and received $0.9 \%$ saline. Solutions were sterile filtered $(0.2 \mu \mathrm{m})$. All animal experiments were approved by the Committee for Animal Experimentation of the University of Ulm and the regional administrative authority (Registration Number 944). All procedures were carried out in accordance with the European Communities Council Directive of November 24, 1986 (86/609/EEC).

\section{Extraction of brain tissue}

At the end of the treatment period, male adolescent rats were anesthetized with carbon dioxide and the brain was removed. The brain hemispheres were sagittally separated and the STR, MES, PFC, and $\mathrm{HC}$ were resected by microdissection. Brain maps from The Rat Brain: In Stereotactic Coordinates. ${ }^{39}$ were used for orientation. All samples were snap-frozen in liquid nitrogen and stored at $-80^{\circ} \mathrm{C}$. All preparations were performed in cold sterile Hank's Balanced Salt Solution (HBSS; PAA Laboratories GmbH, Pasching, Austria).

\section{Extraction of total RNA/quantitative reverse transcription polymerase chain reaction ( $q$ RT-PCR)}

Isolation of total RNA from frozen brain tissue was performed using the RNeasy kit (QIAGEN, Venlo, the Netherlands) as described by the manufacturer. The total RNA was eluted in $60 \mu \mathrm{L}$ RNase-free water. For the reverse transcription (RT)-mediated PCR studies, first strand synthesis and qRTPCR measurements were carried out in a one-step, singletube format using the QIAGEN QuantiFast SYBR Green RT-PCR kit. The qRT-PCR analysis was performed using the Rotor-Gene ${ }^{\circledR}$ real-time PCR machine (QIAGEN). For each measurement, as much as $1 \mu \mathrm{L}$ of undiluted total RNA was measured. RT conditions were as follows: 10 minutes at $50^{\circ} \mathrm{C}, 5$ minutes at $95^{\circ} \mathrm{C}$, followed by 40 cycles of PCR: 10 seconds at $95^{\circ} \mathrm{C}$ for denaturation, 30 seconds at $60^{\circ} \mathrm{C}$ for annealing and elongation. All measurements were run in duplicates. To ascertain primer specificity, melting curves were driven from $60^{\circ} \mathrm{C}$ ramping to $95^{\circ} \mathrm{C}$ in $1{ }^{\circ} \mathrm{C}$ steps, while fluorescence was recorded continuously. The RT and PCR reactions were carried out using QIAGEN QuantiTect Primer Assay oligonucleotides amplifying the following transcripts: solute carrier family 6 member 2 (Slc6a2, QT00184604); glutamate receptor ionotropic $N$-methyl-D-aspartate 1 (Grin1, QT00182287); glutamate receptor ionotropic N-methyl-Daspartate $2 A$ (Grin2A, QT0037928); glutamate receptor ionotropic N-methyl-D-aspartate 2B (Grin2B, QT00184793); synaptophysin (Syp, QT02338056); and synaptosomalassociated protein 25 kDa (Snap25, QT00196413).

\section{Analysis of qRT-PCR data}

Cycle threshold for each run was set to 0.01 . Transcript levels of the transcript of interest were normalized to messenger RNA (mRNA) levels of the $60 \mathrm{~S}$ ribosomal protein L13a (RPL13A), which was calculated to be the most robustly expressed housekeeping gene among six tested genes using a geometric averaging method (geNorm) ${ }^{40,41}$ Other genes tested include tyrosine 3-monooxygenase/tryptophan 5-monooxygenase activation protein, zeta polypeptide, glyceraldehyde3-phosphate dehydrogenase, cyclophilin A, beta-actin, hydroxymethylbilane synthase, RPL13A. Cycle threshold values $\left(\mathrm{Ct}_{\mathrm{v}}\right)$ were inserted in the following formula:

$$
\begin{gathered}
\mathrm{VC}_{\mathrm{TG}}=10^{\wedge}\left(\mathrm{Ct}_{\mathrm{v}} / \text {-slope }\right) \\
\mathrm{VC}_{\mathrm{HKG}}=10^{\wedge}\left(\mathrm{Ct}_{\mathrm{v}} / \text { slope }\right)
\end{gathered}
$$

where $\mathrm{VC}_{\mathrm{TG}}$ is virtual concentration of the target gene (TG) transcripts, and $\mathrm{VC}_{\mathrm{HKG}}$ is virtual concentration of the housekeeping gene (HKG) transcripts. To normalize the expression of the TG to the HKG, ratios were calculated as,

$$
\mathrm{RC}_{\mathrm{TG}}=\mathrm{VC}_{\mathrm{TG}} / \mathrm{VC}_{\mathrm{HKG}}
$$

where $\mathrm{RC}_{\mathrm{TG}}$ is relative concentration of the TG compared to the expression of the HKG. All oligonucleotides used in 
the qRT-PCR were purchased from QIAGEN and display $\sim 100 \%$ efficiency (personal communication with QIAGEN). Therefore, the value of the "-slope" in the above mentioned formula was set to -3.33 , which represents $100 \%$ efficiency.

\section{Preparation of tissue lysates}

Frozen brain tissues were lysed in $100 \mu \mathrm{L}$ (STR, PFC) to $200 \mu \mathrm{L}$ (MES, HC) of sodium dodecyl sulfate (SDS) sample buffer (37.8\% glycerol, 6\% SDS [2x crist], $2.27 \%$ Tris, $2 \%$ bromophenol blue solution [10 mg/mL], $0.15 \%$ dithioerythritol, pH 6.9). Crude lysates were passed through QIAGEN QIAshredder spin columns for 2 minutes at 16,060 rcf. Samples were denatured for 30 minutes at $70^{\circ} \mathrm{C}$ and stored at $-80^{\circ} \mathrm{C}$.

\section{Determination of protein content/coomassie staining}

Protein concentrations of brain lysates were assayed via the amido black staining method. ${ }^{42}$ A calculated $15 \mu \mathrm{g}$ of each sample collected from one brain region was subjected to the same 10\% SDS-polyacrylamide gel electrophoresis. Equal loading was confirmed using total protein stains (GelCode Blue Stain Reagent; Thermo Fisher Scientific, Waltham, MA, USA). ${ }^{43}$

\section{Immunoblotting}

A quantity of $15 \mu \mathrm{g}$ of protein per sample was subjected to $10 \%$ SDS-polyacrylamide gel electrophoresis and separated as appropriate in buffer solution (960 mM glycine, $17 \mathrm{mM}$ SDS, $125 \mathrm{mM}$ Tris). Proteins were electrophoretically transferred ( $90 \mathrm{~V}$ for 105 minutes at $4^{\circ} \mathrm{C}$ ) onto a methanol activated polyvinylidene fluoride membrane using a tank blot transfer system (Bio-Rad Laboratories, Hercules, CA, USA) flooded with buffer solution (195 mM glycine, $25 \mathrm{mM}$ Tris, $20 \%$ methanol, $0.1 \%$ SDS). Blotted membranes were blocked in $5 \%$ fat-free milk dissolved in Tris buffered saline $(150 \mathrm{mM}$ $\mathrm{NaCl}, 50 \mathrm{mM}$ Tris, $\mathrm{pH}$ 7.6) supplemented with $0.05 \%$ Tween 20 (TBST) for 1.5 hours. Membranes were incubated with primary antibodies diluted in blocking solution for 1-1.5 hours. The following primary antibodies were used: rabbit polyclonal antibody against the NET (SAB2102224; Sigma-Aldrich) at a 1:1,000 dilution, ${ }^{44}$ rabbit polyclonal antibody against the NMDAR subunit NR1 (SAB4300405; Sigma-Aldrich) at a dilution of 1:1,000, rabbit polyclonal antibody against the NMDAR subunit NR2A (M-264; Sigma-Aldrich) at $1: 1,000,{ }^{45}$ rabbit polyclonal antibody against the NMDAR subunit NR2B (AP08705PU-N; Acris
Antibodies GmbH, Herford, Germany) at 1:1,000, mouse monoclonal antibody against synaptophysin (Syp) (S 5768; Sigma-Aldrich) at 1:1,000, ${ }^{46}$ and rabbit polyclonal antibody against the synaptosomal-associated protein $25 \mathrm{kDa}$ (Snap25) (ab41455; Abcam, Cambridge, UK) 1:2,000. ${ }^{47}$ Membranes were washed for 30 minutes with three changes of $0.2 \%$ TBST and were incubated in blocking solution supplemented with the following horseradish peroxidase-conjugated secondary antibodies: swine anti-rabbit 1:1,000 (Dako, Glostrup, Denmark) and goat anti-mouse 1:10,000 (DIANOVA GmbH, Hamburg, Germany) for 1 hour, with three 10-minute subsequent wash steps using $0.2 \%$ TBST. Blots were exposed to Pierce ECL Western blot detection reagent (Thermo Fisher Scientific). Photosensitive films (GE Healthcare Europe GmbH, Freiburg, Germany) were exposed to horseradish peroxidase-driven light emission. All steps were performed at room temperature.

\section{Quantification of Western blots}

Films and coomassie stained SDS gels were digitized by scanning without modifying picture properties eg, gain, color, or contrast (HP MP260; Canon, Tokyo, Japan). Densitometry was performed using ImageJ software (available from the US National Institutes of Health) to measure mean grey values of immunoblot signals and coomassie-stained polyacrylamide gels loaded with $5 \mu \mathrm{g}$ of protein. Background areas flanking the respective signals were measured, and the mean background values were subtracted from mean grey values obtained by measuring signals. The background adjusted values of proteins of interest were normalized to the signal intensity of the respective total protein coomassie stainings.

\section{Statistical analysis}

Statistical significance of qRT-PCR values, as well as those from the densitometric measurements of Western blots, were analyzed using a two-tailed Wilcoxon-Mann-Whitney test (SPSS software version 17.0; IBM Corporation, Armonk, NY, USA). Statistical significance was accepted at $P<0.05$, and $P<0.1$ was considered indicative for possible trends.

\section{Results}

\section{Effects of atomoxetine on body weight}

The body weight of the animals was monitored daily during the treatment period to exclude any anorexic effect of atomoxetine. ${ }^{48}$ The adolescent atomoxetine-treated rats displayed no altered weight progression compared to their saline treated littermates (Figure S1). 


\section{Effects of atomoxetine on NMDA receptor and NET}

During the 21-day treatment period (PND 21-42), which is equivalent to childhood and adolescence in humans, atomoxetine altered both mRNA and protein doses of NET and NMDAR subunits 1, 2A, and 2B compared to controls. Detected effects were not evenly distributed throughout the brain, but rather, were identified in distinct brain regions (STR, MES, and HC). Major differences in the brains of rats analyzed immediately after the final atomoxetine application (early treatment group) and those which were housed for 2 more months off-drug (late treatment group) were identified. The PFCs in both groups were not affected by the compound. The results of both mRNA and protein analyses are summarized in Figure 1.

\section{Slc6a2/NET}

Since atomoxetine has a very high affinity to NET (dissociation constant $[\mathrm{Kd}]=0.29 \mathrm{nM}),{ }^{49}$ we addressed the question as to whether Slc6a2 (NET gene) expression and/or its protein amounts are affected after in vivo atomoxetine exposure over a period of 21 days. Measurements of transcript amounts of Slc6a2 revealed no significant alterations in both early and late treatment groups compared to controls (Figure 2A). In contrast, immunoblotting analysis of samples derived from the hippocampus of both treatment groups displayed reduced NET levels compared to saline controls. More specifically, in the $\mathrm{HC}$ of the early treatment group norepinephrine transporter signals were markedly reduced by $32 \% \pm 3.5 \%$ $(P=0.0005)$. In hippocampal samples of rats assigned to the late treatment group, NET levels were also found to be reduced by trend (Figures 1, 2B and C).

\section{Effects of atomoxetine on the NMDAR subunits}

Previously, it has been hypothesized that the onset of ADHD might be linked to a hyperglutamatergic state. ${ }^{11}$ Several magnetic resonance spectroscopy (MRS) studies revealed dysregulations in the glutamatergic system and effects of ADHD drugs on glutamate metabolism. ${ }^{50-53}$ In line with these findings, our group recently demonstrated (in vitro) atomoxetine's antagonistic property at the NMDAR. ${ }^{36}$ Therefore, we addressed the issue of whether atomoxetine affects the expression and/or the protein levels of the three

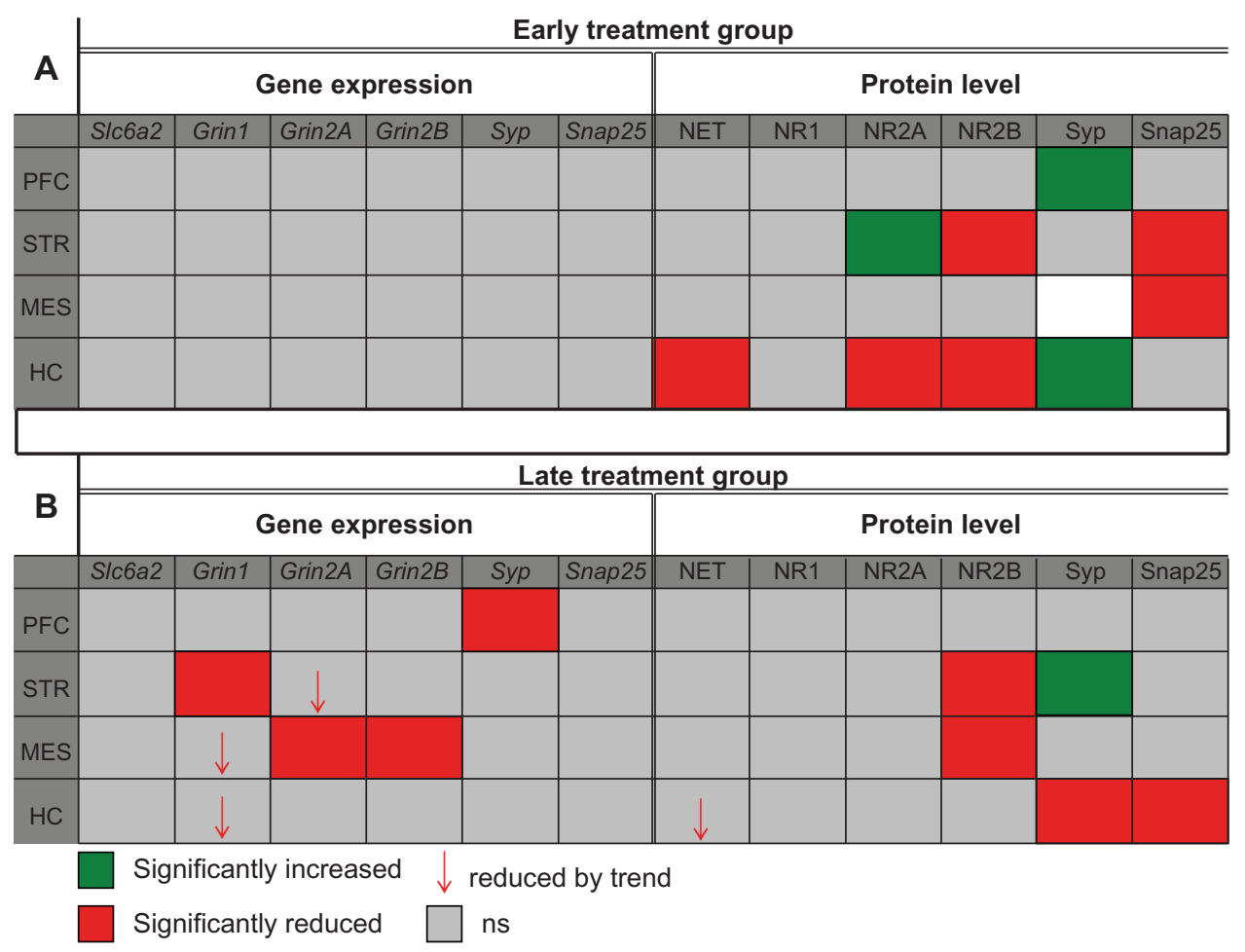

Figure I Summary of the mRNA and protein analysis.

Notes: Summary of results analyzing the early treatment group (PND 2I-42) (A); summary of results analyzing the late treatment group (treatment from PND 2I-42, analysis at PND I0I) (B). Statistical analysis was performed using a two-tailed Wilcoxon-Mann-Whitney test. Significance was accepted at $P<0.05 ; n=7-8$.

Abbreviations: Grin, glutamate receptor ionotropic N-methyl-D-aspartate; HC, hippocampus; MES, mesencephalon; NET, norepinephrine transporter; NR, N-methyl-Daspartate receptor subunit; PFC, prefrontal cortex; PND, postnatal day; Slc6a2, solute carrier family 6 member 2; Snap25, synaptosomal-associated protein 25 kDa; STR, striatum; Syp, synaptophysin; mRNA, messenger RNA. 
Gene expression

A

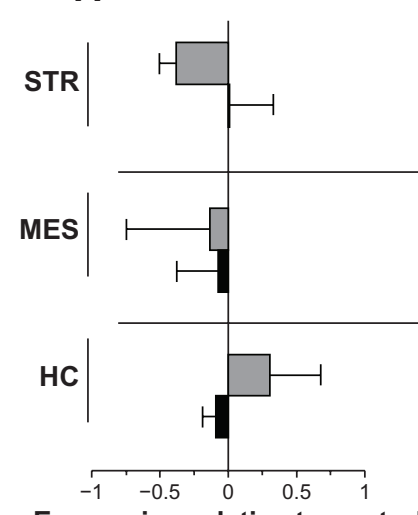

Expression relative to control

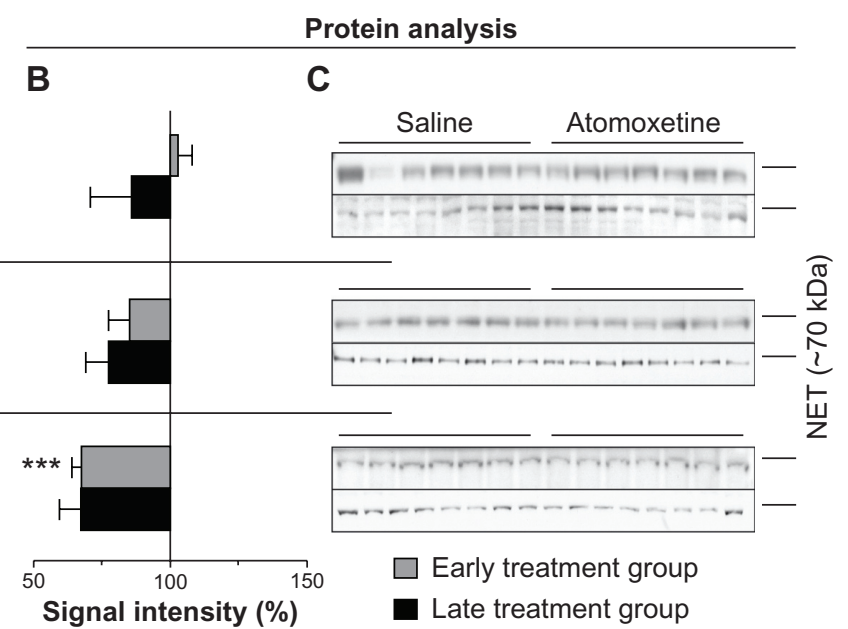

Figure 2 Atomoxetine induced changes on Slc6a2 messenger (m)RNA and NET levels.

Notes: Male adolescent rats were treated for $2 \mathrm{I}$ days (postnatal days $2 \mathrm{I}-4 \mathrm{I})$ with atomoxetine hydrochloride $(3 \mathrm{mg} / \mathrm{kg}$, intraperitoneal [ip]) or saline (0.9\%, ip). The striatum (STR), mesencephalon (MES), and hippocampus (HC) of the early treatment group were analyzed 24 hours after the last ip application, whereas the brains of rats assigned to the late treatment group were probed after a treatment-free period of 2 months. (A) Solute carrier family 6, member 2 (Slc6a2) expression was probed in the STR, MES, and HC. Bar diagrams depict mean values of quantitative reverse transcription polymerase chain reaction (qRT-PCR) measurement. (B) Bar diagrams depict mean values obtained by densitometric quantification of the $(\mathbf{C})$ respective Western blots detecting the norepinephrine transporter (NET) at a molecular weight of $\sim 70 \mathrm{kDa}$. Controls were male age-matched saline-treated rats. All data are presented as \pm standard error of the mean; early treatment group $n=7$; late treatment group $n=8$; $* * * P<0.00 \mathrm{I}$.

main NMDAR subunits, NR1 (Grin1), NR2A (Grin2A), and NR2B $(\operatorname{Grin} 2 B)$ in vivo. Atomoxetine exposure for 21 days reduced the expression and protein amount of the NMDAR subunits in the rat brain compared to controls.

\section{Grin I/NRI}

In the STR of the late treatment group, atomoxetine significantly reduced both mRNA and protein levels of NR1 by $13 \% \pm 4.2 \%(P=0.0498)$ and $36 \% \pm 6.7 \%(P=0.0069)$, respectively (Figure 3). We also identified reduction of Grin 1 mRNA species in MES and HC of the late treatment group. However, statistical analysis of atomoxetine's impact on Grin1 expression in MES and HC revealed only a reduction by trend (Figure 3A). The assayed samples collected from rats assigned to the early treatment group did not elicit significant changes after atomoxetine exposure (Figures 1 and 3).

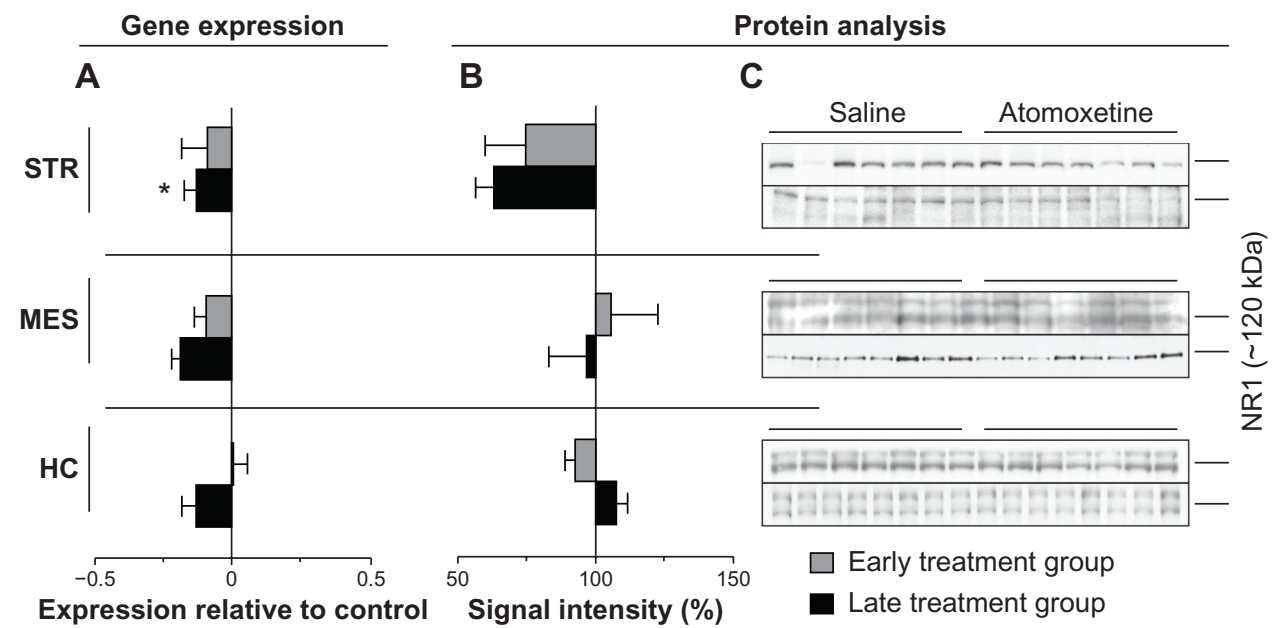

Figure 3 Atomoxetine induced changes on Grinl messenger (m)RNA and NRI levels.

Notes: Male adolescent rats were treated for $2 \mathrm{I}$ days (postnatal days $2 \mathrm{I}-4 \mathrm{I})$ with atomoxetine hydrochloride ( $3 \mathrm{mg} / \mathrm{kg}$, intraperitoneal [ip]) or saline (0.9\%, ip). The striatum (STR), mesencephalon (MES), and hippocampus (HC) of the early treatment group were analyzed 24 hours after the last ip application, whereas the brains of rats assigned to the late treatment group were probed after a treatment-free period of 2 months. (A) Glutamate receptor ionotropic N-methyl-D-aspartate I (Grin I) expression was probed in the STR, MES, and HC. Bar diagrams depict mean values of quantitative reverse transcription polymerase chain reaction (qRT-PCR) measurement. (B) Bar diagrams depict mean values obtained by densitometric quantification of the $(\mathbf{C})$ respective Western blots detecting the glutamate receptor ionotropic $N$-methyl-D-aspartate I (NRI) at a molecular weight of $\sim 120 \mathrm{kDa}$. Controls were male age-matched saline-treated rats. All data are presented as \pm standard error of the mean; early treatment group $\mathrm{n}=6-7$; late treatment group $n=7-8 ; * P<0.05$. 


\section{Grin2A/NR2A}

The qRT-PCR measurements of total RNA isolated from brain regions of the late treatment group, elicited $34 \% \pm 3.2 \%$ lower Grin $2 A$ transcript in MES $(P=0.0069)$ and $16 \% \pm 4.6 \%$ reduced levels of striatal Grin2A $(P=0.0829)$ (Figure 4A). However, the treatment displayed no effect on NR2A protein levels (Figure 4B and C). Furthermore, atomoxetine exposure affected neither Grin $2 A$ expression nor NR2A protein levels in the tested brain regions of the early treatment group (Figures 1 and 4).

\section{Grin2B/NR2B}

Atomoxetine displayed profound impact on Grin $2 B$ expression in the late treatment group. The compound markedly reduced Grin $2 B$ mRNA levels by $50 \% \pm 3.7 \%$ in the MES $(P=0.0206)$ (Figure 5A), whereas mesencephalic NR2B immunoblot signals remained unaltered (Figure 5B and $C$ ). Additionally, we identified significantly reduced NR2B protein levels in the STR $(P=0.0011)$ in both early $(33 \% \pm 8.2 \%$ reduction) and late treatment $(66 \% \pm 3.7 \%$ reduction) groups (Figure 5B and C). Furthermore, hippocampal NR2B amounts in rats assigned to the early treatment group were also found to be lower $(38 \% \pm 8.1 \%$ reduction) compared to saline controls (Figure 5B and C). In contrast, atomoxetine did not affect expression of the probed genes in the analyzed brain regions of animals assigned to the early treatment group.

\section{Provoked alterations in synaptic composition - preliminary findings}

To test the hypothesis concluded from the above mentioned results, if the detected changes in the glutamatergic system mainly decreased levels of NMDAR - would lead to further alterations in the synaptic composition, we investigated the levels of two SNARE (soluble N-ethylmaleimide-sensitive factor attachment protein receptor) proteins, Syp and Snap 25. Both were significantly altered in both treatment groups (Figures 1, 6, and 7).

\section{Discussion}

In the present study, we assessed the question of immediate and long-term impact of a chronic 3-week application of atomoxetine on the NE and glutamatergic system. The assessment was conducted immediately after the 21 days of exposure (early treatment group) and 2 months later (late treatment group).

The administered atomoxetine ip dosage of $3 \mathrm{mg} / \mathrm{kg}$ per day is approximately twice the maximum of the recommended daily dosage in humans. However, considering the much faster metabolism in rats, the applied dosage is well within the therapeutic range. Sprague Dawley rats exposed to this particular atomoxetine dosage for 3 weeks displayed profound changes in both NET and NMDAR subunit transcriptional and translational processes. The effects on mRNA and protein levels of NET and the NMDAR subunits differed across the analyzed

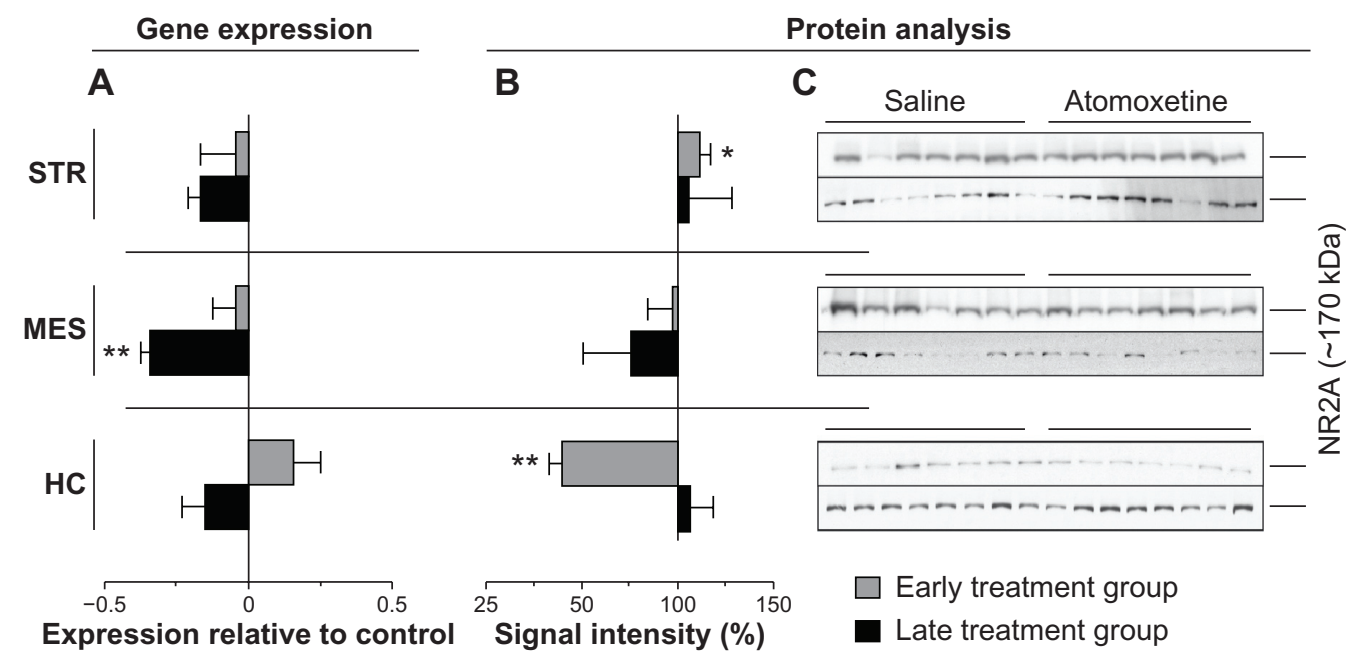

Figure 4 Atomoxetine induced changes on Grin2A messenger (m)RNA and NR2A levels.

Notes: Male adolescent rats were treated for $2 \mathrm{I}$ days (postnatal days $2 \mathrm{I}-4 \mathrm{I})$ with atomoxetine hydrochloride $(3 \mathrm{mg} / \mathrm{kg}$, intraperitoneal [ip]) or saline (0.9\%, ip). The striatum (STR), mesencephalon (MES), and hippocampus $(\mathrm{HC})$ of the early treatment group were analyzed 24 hours after the last ip application, whereas the brains of rats assigned to the late treatment group were probed after a treatment-free period of 2 months. (A) Glutamate receptor ionotropic N-methyl-D-aspartate 2A (Grin2A) expression was probed in the STR, MES, and HC. Bar diagrams depict mean values of quantitative reverse transcription polymerase chain reaction (qRT-PCR) measurement. (B) Bar diagrams depict mean values obtained by densitometric quantification of the $(\mathbf{C})$ respective Western blots detecting the glutamate receptor ionotropic $N$-methyl-D-aspartate $2 A$ (NR2A) at a molecular weight of $\sim 170 \mathrm{kDa}$. Controls were male age-matched saline-treated rats. All data are presented as \pm standard error of the mean, early treatment group $\mathrm{n}=7$, late treatment group $n=8 ; * P<0.05 ; * * P<0.0$ l. 


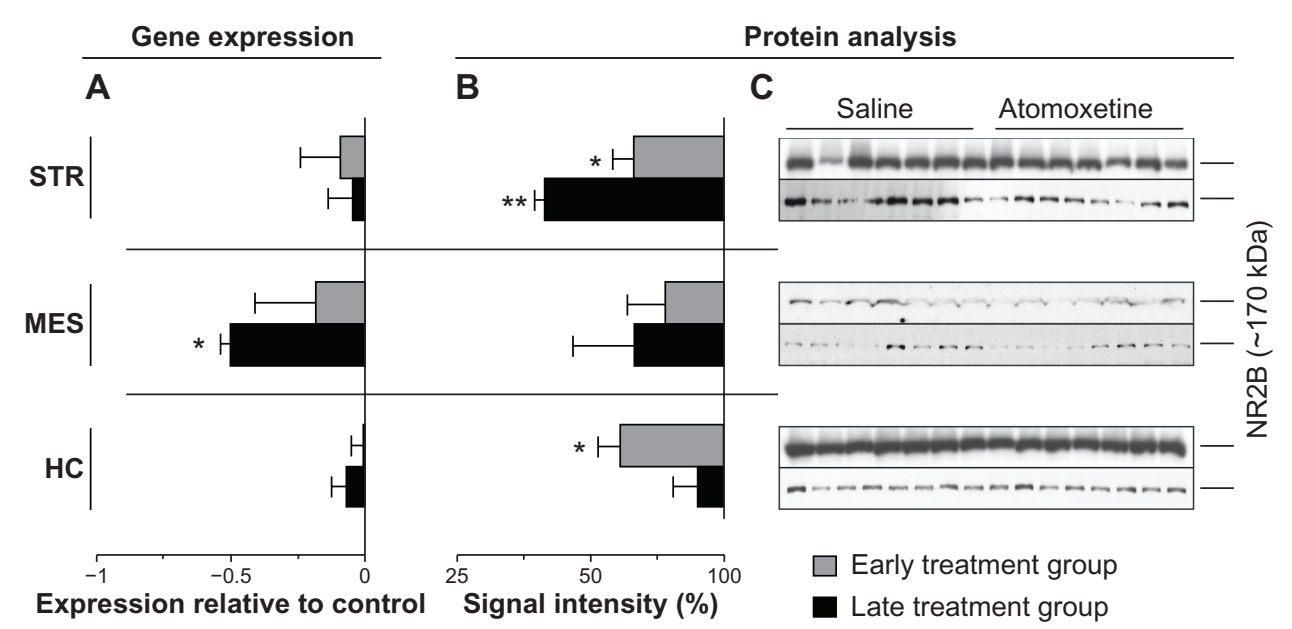

Figure 5 Atomoxetine induced changes on Grin2B messenger (m)RNA and NR2B levels.

Notes: Male adolescent rats were treated for $2 \mathrm{I}$ days (postnatal days $2 \mathrm{I}-4 \mathrm{I})$ with atomoxetine hydrochloride (3 mg/kg, intraperitoneal [ip]) or saline (0.9\%, ip). The striatum (STR), mesencephalon (MES), and hippocampus (HC) of the early treatment group were analyzed 24 hours after the last ip application, whereas the brains of rats assigned to the late treatment group were probed after a treatment-free period of 2 months. (A) Glutamate receptor ionotropic N-methyl-D-aspartate 2B (Grin2B) expression was probed in the STR, MES, and HC. Bar diagrams depict mean values of quantitative reverse transcription polymerase chain reaction (qRT-PCR) measurement. (B) Bar diagrams depict mean values obtained by densitometric quantification of the $(\mathbf{C})$ respective Western blots detecting the glutamate receptor ionotropic $N$-methyl- $D$-aspartate $2 B$ (NR2B) at a molecular weight of $\sim 170 \mathrm{kDa}$. Controls were male age-matched saline-treated rats. All data are presented as \pm standard error of the mean; early treatment group $\mathrm{n}=7$; late treatment group $\mathrm{n}=8 ; * \mathrm{p}<0.05$; $* * \mathrm{p}<0.0 \mathrm{I}$.

treatment groups and assayed brain regions. Taking the age of the animals into account (PND 21-42), which is the treatment period equivalent to childhood and early adolescence in humans, atomoxetine displays strong impact on brain biochemistry, thus underpinning the compound's impact on cerebral development already after only 21 days of treatment.

Assaying protein levels of the reported primary biochemical target of atomoxetine, NET levels in both early and late treatment group $\mathrm{HC}$ samples were reduced compared to controls. However, the impact of the substance had no effect on the transporter's gene expression. As Bymaster et $\mathrm{al}^{27}$ showed in their combined in vivo and in vitro study, atomoxetine inhibits radioligand binding in cells transfected with human NETs with binding affinity (Ki) values of $5 \mathrm{nM}$. For illustration purposes, note that recommended serum levels in humans, treated with atomoxetine, are in the range of $200-1,000 \mathrm{ng} / \mathrm{mL}$, equivalent to $0.6-3.4 \mu \mathrm{M} .^{33}$ Presumably, brain concentrations are even higher. ${ }^{34}$ Therefore, atomoxetine probably displays strong NE reuptake inhibitory effects, which in consequence, might have triggered

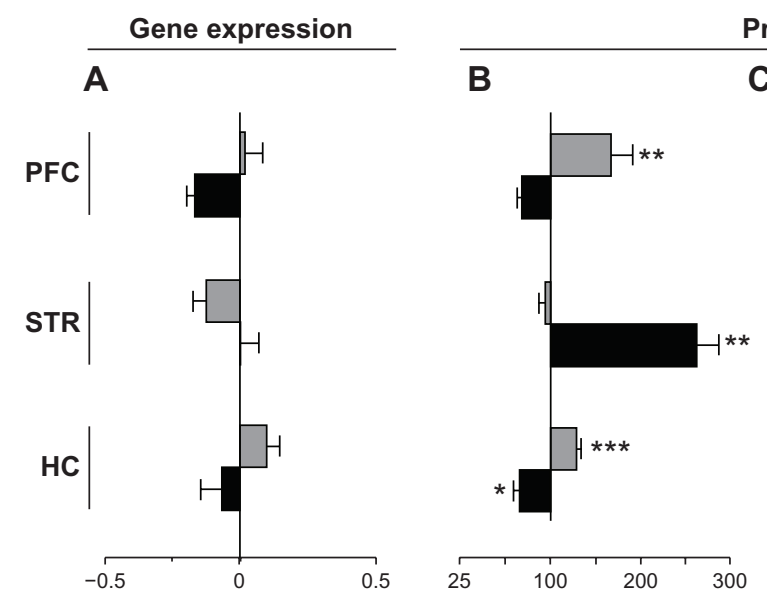

Expression relative to control Signal intensity (\%)
Protein analysis

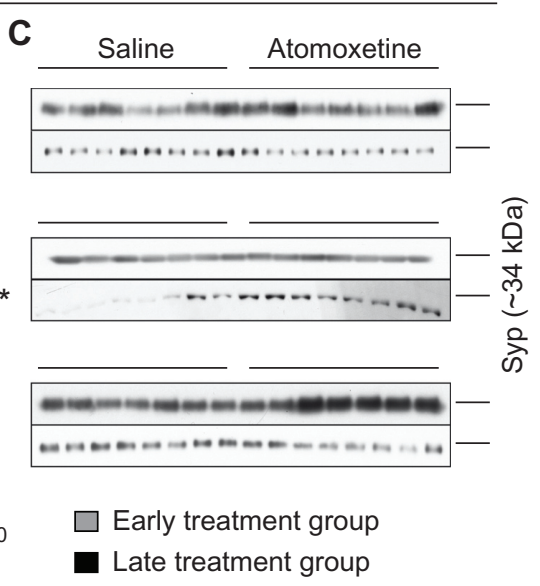

Figure 6 Atomoxetine induced changes on Syp messenger $(\mathrm{m})$ RNA and protein levels.

Notes: Male adolescent rats were treated for 21 days (postnatal days $2 \mathrm{l}-4 \mathrm{l})$ with atomoxetine hydrochloride $(3 \mathrm{mg} / \mathrm{kg}$, intraperitoneal [ip]) or saline (0.9\%, ip). The prefrontal cortex (PFC), striatum (STR), and hippocampus (HC) of the early treatment group were analyzed 24 hours after the last ip application, whereas the brains of rats assigned to the late treatment group were probed after a treatment-free period of 2 months. (A) Synaptophysin (Syp) expression was probed in the PFC, STR, and HC. Bar diagrams depict mean values of quantitative reverse transcription polymerase chain reaction (qRT-PCR) measurement. (B) Bar diagrams depict mean values obtained by densitometric quantification of the $(\mathbf{C})$ respective Western blots detecting Syp (I:1000) at a molecular weight of $\sim 34 \mathrm{kDa}$. Controls were male age-matched saline-treated rats. All data are presented as \pm standard error of the mean; early treatment group $n=7$; late treatment group $n=8 ; * P<0.05 ; * * P<0.01$; $* * * P<0.00 \mathrm{I}$. 


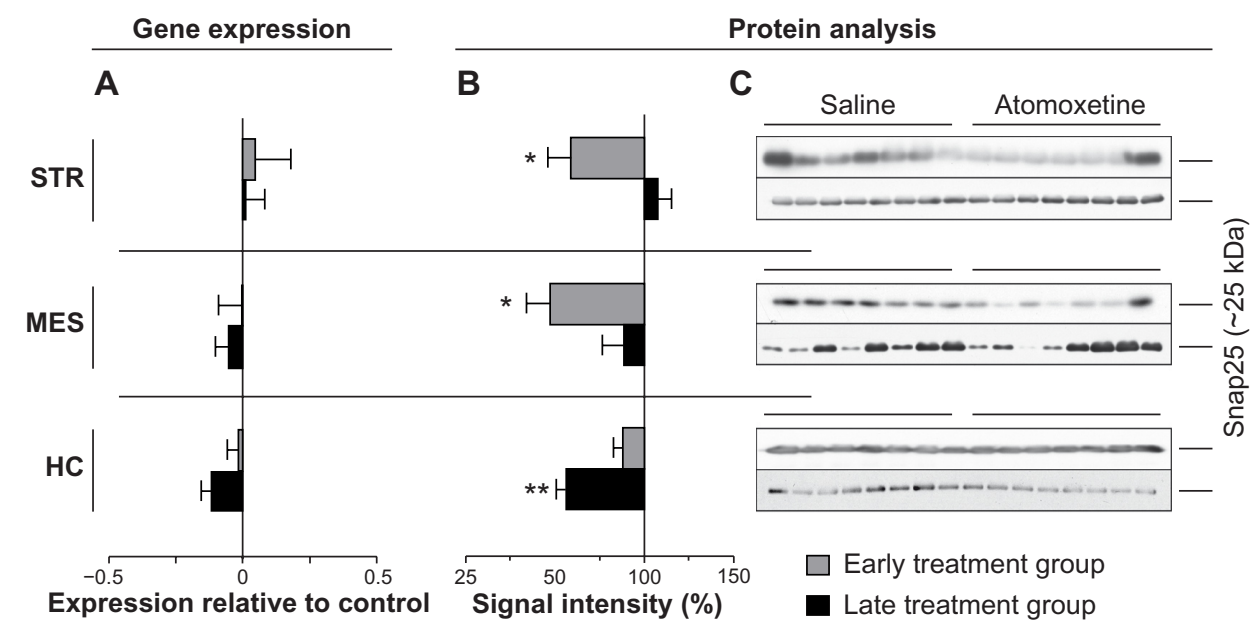

Figure 7 Atomoxetine induced changes on Snap25 messenger (m)RNA and protein levels.

Notes: Male adolescent rats were treated for $2 \mathrm{I}$ days (postnatal days $2 \mathrm{I}-4 \mathrm{I})$ with atomoxetine hydrochloride $(3 \mathrm{mg} / \mathrm{kg}$, intraperitoneal [ip]) or saline (0.9\%, ip). The striatum (STR) and hippocampus ( $\mathrm{HC}$ ) of the early treatment group were analyzed 24 hours after the last ip application, whereas the brains of rats assigned to the late treatment group were probed after a treatment-free period of 2 months. (A) Synaptosomal-associated protein $25 \mathrm{kDa}$ (Snap25) expression was probed in the STR, MES, and HC. Bar diagrams depict mean values of quantitative reverse transcription polymerase chain reaction (qRT-PCR) measurement. (B) Bar diagrams depict mean values obtained by densitometric quantification of the $(\mathbf{C})$ respective Western blots detecting the Snap25 (I:50,000) at a molecular weight of $\sim 25 \mathrm{kDa}$. Controls were male age-matched saline-treated rats. All data are presented as \pm standard error of the mean; early treatment group $n=7$; late treatment group $n=8 ; * P<0.05 ; * * P<0.0$ l.

Abbreviation: MES, mesencephalon.

the observed reduction of NET levels. Furthermore, altered NET levels might also be indirectly linked to atomoxetine's NMDAR antagonistic effect. As reviewed by Duguid and Smart, ${ }^{54}$ presynaptic NMDARs affect synaptic transmission ${ }^{55}$ by modifying neurotransmitter release via $\mathrm{Ca}^{2+}$ entry and influencing transmitter release of presynaptic vesicles and their fusion with the presynaptic membrane. ${ }^{56,57}$ Pittaluga and Raiteri ${ }^{58}$ have demonstrated increased NE release in HC modulated by presynaptic NMDARs. Atomoxetine may inhibit these presynaptic NMDARs, ${ }^{23}$ resulting in altered transmitter release, which modulates the presynapse by affecting proteins localized to the presynapse. To strengthen our hypothesis of atomoxetine's effect at the presynapse, we additionally assayed the presynaptic vesicle marker Syp and the Snap25, known to be crucial for vesicle fusion and transmitter release into the synaptic cleft. Analysis of the two proteins revealed significant alterations in the STR and HC of both early and late treatment groups (Figures 6 and 7). Furthermore, we observed significantly reduced protein levels of hippocampal NR2B in the early treatment group and lower Grin 1 mRNA amounts in the $\mathrm{HC}$ of the late treatment group. Due to the nature of the techniques used, we cannot allocate the effects on the NMDAR subunits to the presynapse or postsynapse. However, our findings of altered NMDAR subunit mRNA and protein levels correlate with the changes of NET levels and altered proteins crucial for transmitter release in the $\mathrm{HC}$ of both treatment groups. Therefore, we hypothesize that in our in vivo study, atomoxetine treatment had a profound impact on the presynapse.
Previously, the modulatory effect of two other NMDAR antagonists, acamprosate and MK-801 (dizocilpine), on transcript and protein levels of NMDAR subunits has been demonstrated in the rat brain. ${ }^{59}$ Rammes et al demonstrated significantly increased mRNA and protein levels in the $\mathrm{HC}$ and cortex after a single ip dose in adult male Wistar rats. ${ }^{59}$ At first glance their results seem to be contrary to our findings; however, in the present study, younger rats from a different strain were probed. The two NMDAR inhibitors used by Rammes et al to block the receptor channel have diverse chemical and biochemical properties compared to atomoxetine. The chronic exposure to atomoxetine (21 days) obviously triggers diverse effects on gene expression and protein amounts of the ionotropic glutamate receptors. The discrepancies between the findings of the two studies might be due to the different age of the groups; NMDA receptors undergo prominent changes during brain development, ${ }^{60,61}$ such as altered subunit composition, which changes their functionality ${ }^{62}$ and modifies their pharmacological response. ${ }^{14,63,64}$

Notably, alterations of gene expression were only found in the late treatment group. The impact on NMDAR subunit protein levels was also evident, as they increased in the late treatment group, indicating that atomoxetine influences brain development far beyond the direct pharmacological effect. Atomoxetine seems to stimulate a change in synaptic composition that even amplifies in the course of development.

Another issue to address is the apparent discrepancy between effects on mRNA and protein levels. As we 
compared the effects of atomoxetine on mRNA and protein level, we identified statistically significant alterations of both entities, but did not find congruent results. In general, mRNA and protein quantities approximately correlated. However, in a correlation study by Guo et al, ${ }^{65}$ the expression profile of 71 genes and their respective proteins in circulating monocytes collected from 30 unrelated women were investigated. Considering the whole dataset, the authors found a striking correlation between mRNA and protein amounts, but only five genes displayed close correlation to their corresponding proteins at the study group level. Furthermore, they observed that only $9 \%$ of the protein variation was directly linked to changes in the amount of the respective mRNA species. Guo et al concluded that gene expression and protein level correlation differ between individuals. ${ }^{65}$ Considering that in the present study, an outbred rat strain was analyzed harboring large genetic heterogeneity, our contradictory findings of effects on transcript and protein level are comprehensible. Taken together, atomoxetine seems to reduce gene expression and protein levels of NET and NMDARs, leading to further regulation of synaptic composition.

\section{Clinical implications}

The involvement of the glutamatergic system in the pathophysiology of ADHD is recently coming more distinctly into view. ${ }^{10,11}$ In a first MRS study, MacMaster et al ${ }^{66}$ detected an increase in glutamatergic tone in untreated children with ADHD compared to controls. In another study, the group investigated 14 children with ADHD, medication-free, and after treatment. ${ }^{52}$ Eleven out of 14 children were treated with psychostimulants, only three with atomoxetine. The striatal glutamate/glutamine/gammaaminobutyric acid to creatine/phosphocreatine ratio was the only detectable change in response to medication. The ratio decreased significantly. The authors postulated that an influence on glutamate metabolism might be involved in treatment response in ADHD. Also, Wiguna et al found a decreased glutamate to creatine ratio after treatment by MRS (21 children with ADHD). ${ }^{51}$ In this study, it was not the STR where the findings were significant but in the PFC.

The ubiquitous neurotransmitter glutamate - nearly $60 \%$ of all neuronal synapses in the brain are glutamatergic ${ }^{12}$ - is essential as a neuronal growth factor and is pivotal during neuronal development. ${ }^{67}$ Recently, two open-label studies with the NMDA antagonist memantine $(20 \mathrm{mg} /$ day) in pediatric and adult ADHD patients showed positive effects on clinical symptoms. ${ }^{68}$ Earlier studies pointed out the pivotal role of the NR2B subunit in neuron excitability and synaptic plasticity. ${ }^{69,70}$ Jensen et al ${ }^{22}$ could show that hippocampal LTP in the SHR (PND 28), the best validated animal model of ADHD, was significantly reduced by an NR2B specific blocker, whereas the blocker had no effect in the age-matched control animals. The authors interpreted their results as a functional predominance of NR2B in SHR, meaning a delayed development. At PND 28, NR2Acontaining NMDARs usually contribute substantially to LTP induction. ${ }^{14,15}$

In the present study, atomoxetine significantly reduced the protein level of NR2B in the HC of the adolescent rats. This action might contribute to the clinical effects of the compound.

Genome-wide association studies on ADHD patients pointed out that the modulation of neuronal and synaptic plasticity seems to be at least one of the essential mechanisms in ADHD pathophysiology, ${ }^{71-73}$ even though, as reviewed by Franke et al, ${ }^{74}$ the results of the existing genome-wide association studies showed limited overlap.

Besides dysfunctions in neuronal glutamate transmission, increasing evidence emphasizes that abnormal neuronal development, such as disturbed synaptogenesis and/ or dysfunctional neuronal migration, is important in ADHD pathophysiology. ${ }^{75}$

In the present in vivo study, the majority of the reported effects of atomoxetine were identified in the STR and HC. Already in 1996, Lou ${ }^{25}$ pointed out the unique anatomical characteristics of the STR, a watershed region with convergent glutamatergic afferent projections from almost the entire cortex. In ischemia-induced liberation of glutamate, this accentuated position of the STR is the cause of its particular vulnerability to lesions. Besides genetic factors, pre- and perinatal events are hypothesized to be a predominant cause for ADHD. ${ }^{25}$ The observed cellular mechanisms of atomoxetine in this in vivo study might at least contribute to the clinical effects ameliorating ADHD core symptoms.

\section{Limitations}

This study revealed new insights of atomoxetine's biological properties at the cellular level. Nevertheless, some limitations of the study must be considered. The Sprague Dawley rats from Charles River are an outbred strain; the heterogeneity of the genetic background probably masked minor effects on gene expression and protein levels. In some cases of probed mRNA species the interindividual variation was very high. A further limitation is the total number of animals $(n=7-8)$ per experiment, which was strongly regulated by regional administrative authorities. 


\section{Conclusion}

In conclusion, the results of the present exploratory study demonstrate that atomoxetine's impact on the brain is not solely limited to the inhibition of NE reuptake. The compound alters mRNA and protein levels of the respective genes and proteins crucial for synaptic plasticity, hence influencing the neuronal homoeostasis, ${ }^{76}$ which presumably is disturbed in ADHD. Two actions especially might be of major interest: first, the reduction of the NMDA receptor subunit NR2B in the adolescent $\mathrm{HC}$ since this protein seems to be elevated in the $\mathrm{HC}$ of the best validated animal model of ADHD, the SHR, ${ }^{22}$ and second, the influence on Snap25, a novel candidate gene which has been altered in the coloboma mouse, another animal model for ADHD. ${ }^{77,78}$

Furthermore, we showed that atomoxetine's immediate and long-term effects on synaptic proteins differ, thus emphasizing its modulatory influence on synaptic plasticity. However, whether atomoxetine's impact can directly be linked to its NMDAR and NET antagonism or is due to a still unknown pathway has yet to be elucidated. In the present study, we were able to show immediate and long-term brain region-specific effects. Disease-specific effects must be investigated in animal models of ADHD, ie, in the above mentioned SHR. ${ }^{79,80}$

\section{Disclosure}

Professor, Dr Andrea G Ludolph has received research funding from UCB/Celltech, Medice, and Novartis. She was/ is involved in clinical trials with Boehringer Ingelheim, Shire, and Otsuka. She discloses consulting fees and travel grants from Shire and lecture fees from Janssen and Lilly. Patrick T Udvardi, Dr Stefan Liebau, Carolin Henes, Dr Karl Föhr, Dr Jens Dreyhaupt, and Professor Tobias M Boeckers report no conflicts of interest in this work.

\section{References}

1. Polanczyk G, de Lima MS, Horta BL, Biederman J, Rohde LA. The worldwide prevalence of ADHD: a systematic review and metaregression analysis. Am J Psychiatry. 2007;164(6):942-948.

2. Biederman J, Faraone SV. Attention-deficit hyperactivity disorder. Lancet. 2005;366(9481):237-248.

3. Spencer TJ, Biederman J, Mick E. Attention-deficit/hyperactivity disorder: diagnosis, lifespan, comorbidities, and neurobiology. J Pediatr Psychol. 2007;32(6):631-642.

4. Kessler RC, Adler L, Barkley R, et al. The prevalence and correlates of adult ADHD in the United States: results from the National Comorbidity Survey Replication. Am J Psychiatry. 2006;163(4):716-723.

5. Stahl S. Attention deficit hyperactivity disorder and its treatmented. In: Stahl S, editor. Stahl's Essential Psychopharmacocogy. 3rd ed. New York, NY: Cambridge University Press; 2008:863-897.

6. Gibson AP, Bettinger TL, Patel NC, Crismon ML. Atomoxetine versus stimulants for treatment of attention deficit/hyperactivity disorder. Ann Pharmacother. 2006;40(6):1134-1142.
7. Molina BS, Hinshaw SP, Swanson JM, et al; MTA Cooperative Group. The MTA at 8 years: prospective follow-up of children treated for combined-type ADHD in a multisite study. J Am Acad Child Adolesc Psychiatry. 2009;48(5):484-500.

8. Ferris RM, Tang FL, Maxwell RA. A comparison of the capacities of isomers of amphetamine, deoxypipradrol and methylphenidate to inhibit the uptake of tritiated catecholamines into rat cerebral cortex slices, synaptosomal preparations of rat cerebral cortex, hypothalamus and striatum and into adrenergic nerves of rabbit aorta. J Pharmacol Exp Ther. 1972;181(3):407-416.

9. Schweri MM, Skolnick P, Rafferty MF, Rice KC, Janowsky AJ, Paul SM. [3H]Threo-(+/-)-methylphenidate binding to 3,4dihydroxyphenylethylamine uptake sites in corpus striatum: correlation with the stimulant properties of ritalinic acid esters. $J$ Neurochem. 1985;45(4):1062-1070.

10. Carrey NJ, MacMaster FP, Gaudet L, Schmidt MH. Striatal creatine and glutamate/glutamine in attention-deficit/hyperactivity disorder. J Child Adolesc Psychopharmacol. 2007;17(1):11-17.

11. Lule D, Ludolph AC, Ludolph AG. Neurodevelopmental and neurodegenerative diseases - is there a pathophysiological link? Attention-deficit/hyperactivity disorder and amyotrophic lateral sclerosis as examples. Med Hypotheses. 2008;70(6):1133-1138.

12. Orrego F, Villanueva S. The chemical nature of the main central excitatory transmitter: a critical appraisal based upon release studies and synaptic vesicle localization. Neuroscience. 1993;56(3): 539-555.

13. Davies J, Evans RH, Francis AA, Watkins JC. Excitatory amino acid receptors and synaptic excitation in the mammalian central nervous system. J Physiol (Paris). 1979;75(6):641-654.

14. Cull-Candy S, Brickley S, Farrant M. NMDA receptor subunits: diversity, development and disease. Curr Opin Neurobiol. 2001;11(3): 327-335.

15. Köhr G, Jensen V, Koester HJ, et al. Intracellular domains of NMDA receptor subtypes are determinants for long-term potentiation induction. J Neurosci. 2003;23(34):10791-10799.

16. Monyer H, Burnashev N, Laurie DJ, Sakmann B, Seeburg PH. Developmental and regional expression in the rat brain and functional properties of four NMDA receptors. Neuron. 1994;12(3):529-540.

17. Stocca G, Vicini S. Increased contribution of NR2A subunit to synaptic NMDA receptors in developing rat cortical neurons. J Physiol. 1998;507(Pt 1):13-24.

18. Tovar KR, Westbrook GL. The incorporation of NMDA receptors with a distinct subunit composition at nascent hippocampal synapses in vitro. J Neurosci. 1999;19(10):4180-4188.

19. Li B, Chen N, Luo T, Otsu Y, Murphy TH, Raymond LA. Differential regulation of synaptic and extra-synaptic NMDA receptors. Nat Neurosci. 2002;5(9):833-834.

20. Köhr G. NMDA receptor function: subunit composition versus spatial distribution. Cell Tissue Res. 2006;326(2):439-446.

21. Hardingham GE, Fukunaga Y, Bading H. Extrasynaptic NMDARs oppose synaptic NMDARs by triggering CREB shut-off and cell death pathways. Nat Neurosci. 2002;5(5):405-414.

22. Jensen V, Rinholm JE, Johansen TJ, et al. N-methyl-D-aspartate receptor subunit dysfunction at hippocampal glutamatergic synapses in an animal model of attention-deficit/hyperactivity disorder. Neuroscience. 2009;158(1):353-364.

23. Malinow R, Malenka RC. AMPA receptor trafficking and synaptic plasticity. Annu Review Neurosci. 2002;25:103-126.

24. Bredt DS, Nicoll RA. AMPA receptor trafficking at excitatory synapses. Neuron. 2003;40(2):361-379.

25. Lou HC. Etiology and pathogenesis of attention-deficit hyperactivity disorder (ADHD): significance of prematurity and perinatal hypoxic-haemodynamic encephalopathy. Acta Paediatr. 1996;85(11): 1266-1271.

26. Gehlert DR, Schober DA, Gackenheimer SL. Comparison of (R)-[3H] tomoxetine and $(\mathrm{R} / \mathrm{S})-[3 \mathrm{H}]$ nisoxetine binding in rat brain. JNeurochem . $1995 ; 64(6): 2792-2800$. 
27. Bymaster FP, Katner JS, Nelson DL, et al. Atomoxetine increases extracellular levels of norepinephrine and dopamine in prefrontal cortex of rat: a potential mechanism for efficacy in attention deficit/hyperactivity disorder. Neuropsychopharmacology. 2002;27(5):699-711.

28. Easton N, Steward C, Marshall F, Fone K, Marsden C. Effects of amphetamine isomers, methylphenidate and atomoxetine on synaptosomal and synaptic vesicle accumulation and release of dopamine and noradrenaline in vitro in the rat brain. Neuropharmacology. 2007;52(2):405-414.

29. Peterson K, McDonagh MS, Fu R. Comparative benefits and harms of competing medications for adults with attention-deficit hyperactivity disorder: a systematic review and indirect comparison meta-analysis. Psychopharmacology (Berl). 2008;197(1):1-11.

30. Seneca N, Gulyás B, Varrone A, et al. Atomoxetine occupies the norepinephrine transporter in a dose-dependent fashion: a PET study in nonhuman primate brain using (S,S)-[18F]FMeNER-D2. Psychopharmacology (Berl). 2006;188(1):119-127.

31. Takano A, Gulyás B, Varrone A, Maguire RP, Halldin C. Saturated norepinephrine transporter occupancy by atomoxetine relevant to clinical doses: a rhesus monkey study with (S,S)-[(18)F]FMeNER-D (2). Eur J Nucl Med Mol Imaging. 2009;36(8):1308-1314.

32. Kratochvil CJ, Heiligenstein JH, Dittmann R, et al. Atomoxetine and methylphenidate treatment in children with ADHD: a prospective, randomized, open-label trial. J Am Acad Child Adolesc Psychiatry. 2002;41(7):776-784.

33. Hiemke C, Baumann P, Bergemann N, et al. AGNP consensus guidelines for therapeutic drug monitoring in psychiatry: update 2011. Pharmacopsychiatry. 2011;44(6):195-235.

34. Kielbasa W, Kalvass JC, Stratford R. Microdialysis evaluation of atomoxetine brain penetration and central nervous system pharmacokinetics in rats. Drug Metab Dispos. 2009;37(1):137-142.

35. Scherer D, Hassel D, Bloehs R, et al. Selective noradrenaline reuptake inhibitor atomoxetine directly blocks hERG currents. Br J Pharmacol. 2009;156(2):226-236.

36. Ludolph AG, Udvardi PT, Schaz U, et al. Atomoxetine acts as an NMDA receptor blocker in clinically relevant concentrations. Br J Pharmacol. 2010;160(2):283-291.

37. Lempp T, Toennes SW, Wunder C, et al. Altered gene expression in the prefrontal cortex of young rats induced by the ADHD drug atomoxetine. Prog Neuropsychopharmacol Biol Psychiatry. 2013;40: 221-228.

38. Ikonomidou C, Bittigau $\mathrm{P}$, Koch $\mathrm{C}$, et al. Neurotransmitters and apoptosis in the developing brain. Biochem Pharmacol. 2001;62(4): 401-405.

39. Paxinos G, Watson C. The Rat Brain: In Stereotactic Coordinates. 2nd Ed. London: Academic Press; 1986.

40. Vandesompele J, De Preter K, Pattyn F, et al. Accurate normalization of real-time quantitative RT-PCR data by geometric averaging of multiple internal control genes. Genome biology. RESEARCH0034. 2002;3(7)

41. Mestdagh P, Van Vlierberghe P, De Weer A, et al. A novel and universal method for microRNA RT-qPCR data normalization. Genome biology. 2009;10(6):R64.

42. Schaffner W, Weissmann C. A rapid, sensitive, and specific method for the determination of protein in dilute solution. Anal Biochem. 1973;56(2):502-514.

43. Aldridge GM, Podrebarac DM, Greenough WT, Weiler IJ. The use of total protein stains as loading controls: an alternative to high-abundance single-protein controls in semi-quantitative immunoblotting. J Neurosci Methods. 2008;172(2):250-254.

44. Bayles R, Harikrishnan KN, Lambert E, et al. Epigenetic modification of the norepinephrine transporter gene in postural tachycardia syndrome. Arterioscler Thromb Vasc Biol. 2012;32(8):1910-1916.

45. Altafaj X, Ortiz-Abalia J, Fernández M, et al. Increased NR2A expression and prolonged decay of NMDA-induced calcium transient in cerebellum of TgDyrk1A mice, a mouse model of Down syndrome. Neurobiol Dis. 2008;32(3):377-384.
46. Uriu Y, Kiyonaka S, Miki T, et al. Rab3-interacting molecule gamma isoforms lacking the Rab3-binding domain induce long lasting currents but block neurotransmitter vesicle anchoring in voltage-dependent P/Qtype Ca2+ channels. J Biol Chem. 2010;285(28):21750-21767.

47. Chalazonitis A, Tang AA, Shang Y, et al. Homeodomain interacting protein kinase 2 regulates postnatal development of enteric dopaminergic neurons and glia via BMP signaling. J Neurosci. 2011;31(39):13746-13757.

48. Michelson D, Faries D, Wernicke J, et al; Atomoxetine ADHD Study Group. Atomoxetine in the treatment of children and adolescents with attention-deficit/hyperactivity disorder: a randomized, placebocontrolled, dose-response study. Pediatrics. 2001;108(5):E83.

49. Gehlert DR, Gackenheimer SL, Robertson DW. Localization of rat brain binding sites for $[3 \mathrm{H}]$ tomoxetine, an enantiomerically pure ligand for norepinephrine reuptake sites. Neurosci Lett. 1993;157(2):203-206.

50. Arcos-Burgos M, Londoño AC, Pineda DA, et al. Analysis of brain metabolism by proton magnetic resonance spectroscopy (1H-MRS) in attention-deficit/hyperactivity disorder suggests a generalized differential ontogenic pattern from controls. Atten Defic Hyperact Disord. 2012;4(4):205-212.

51. Wiguna T, Guerrero APS, Wibisono S, Sastroasmoro S. Effect of 12-week administration of 20-mg long-acting methylphenidate on $\mathrm{Glu} / \mathrm{Cr}, \mathrm{NAA} / \mathrm{Cr}, \mathrm{Cho} / \mathrm{Cr}$, and $\mathrm{mI} / \mathrm{Cr}$ ratios in the prefrontal cortices of school-age children in Indonesia: a study using $1 \mathrm{H}$ magnetic resonance spectroscopy (MRS). Clin Neuropharmacol. 2012;35(2):81-85.

52. Carrey N, MacMaster FP, Fogel J, et al. Metabolite changes resulting from treatment in children with ADHD: a $1 \mathrm{H}-\mathrm{MRS}$ study. Clin Neuropharmacol. 2003;26(4):218-221.

53. Tafazoli S, O’Neill J, Bejjani A, et al. 1H MRSI of middle frontal gyrus in pediatric ADHD. J Psychiatr Res. 2013;47(4):505-512.

54. Duguid IC, Smart TG. Presynaptic NMDAR receptors. In: VanDongen AM, editor. Biology of the NMDAR Receptor. Boca Raton, FL: CRC Press; 2009:313-328.

55. Langer SZ. Presynaptic autoreceptors regulating transmitter release. Neurochem Int. 2008;52(1-2):26-30.

56. Stevens CF. Presynaptic function. Curr Opin Neurobiol. 2004;14(3): 341-345.

57. Sudhof TC. The synaptic vesicle cycle. Annu Rev Neurosci. 2004;27: 509-547.

58. Pittaluga A, Raiteri M. N-methyl-D-aspartic acid (NMDA) and nonNMDA receptors regulating hippocampal norepinephrine release. III. Changes in the NMDA receptor complex induced by their functional cooperation. J Pharmacol Exp Ther. 1992;263(1):327-333.

59. Rammes G, Mahal B, Putzke J, et al. The anti-craving compound acamprosate acts as a weak NMDA-receptor antagonist, but modulates NMDA-receptor subunit expression similar to memantine and MK-801. Neuropharmacology. 2001;40(6):749-760.

60. Sheng M, Cummings J, Roldan LA, Jan YN, Jan LY. Changing subunit composition of heteromeric NMDA receptors during development of rat cortex. Nature. 1994;368(6467):144-147.

61. Wenzel A, Fritschy JM, Mohler H, Benke D. NMDA receptor heterogeneity during postnatal development of the rat brain: differential expression of the NR2A, NR2B, and NR2C subunit proteins. J Neurochem. 1997;68(2):469-478.

62. Barria A, Malinow R. NMDA receptor subunit composition controls synaptic plasticity by regulating binding to CaMKII. Neuron. 2005;48(2):289-301.

63. Martin D, Bustos GA, Bowe MA, Bray SD, Nadler JV. Autoreceptor regulation of glutamate and aspartate release from slices of the hippocampal CA1 area. J Neurochem. 1991;56(5):1647-1655.

64. Paoletti P, Neyton J. NMDA receptor subunits: function and pharmacology. Curr Opin Pharmacol. 2007;7(1):39-47.

65. Guo Y, Xiao P, Lei S, et al. How is mRNA expression predictive for protein expression? A correlation study on human circulating monocytes. Acta Biochim Biophys Sin (Shanghai). 2008;40(5):426-436.

66. MacMaster FP, Carrey N, Sparkes S, Kusumakar V. Proton spectroscopy in medication-free pediatric attention-deficit/hyperactivity disorder. Biol Psychiatry. 2003;53(2):184-187. 
67. Ikonomidou C, Bosch F, Miksa M, et al. Blockade of NMDA receptors and apoptotic neurodegeneration in the developing brain. Science. 1999;283(5398):70-74.

68. Findling RL, Short EJ, McNamara NK, et al. Methylphenidate in the treatment of children and adolescents with bipolar disorder and attention-deficit/hyperactivity disorder. J Am Acad Child Adolesc Psychiatry. 2007;46(11):1445-1453.

69. Standaert DG, Testa CM, Young AB, Penney JB. Organization of $\mathrm{N}$-methyl-D-aspartate glutamate receptor gene expression in the basal ganglia of the rat. J Comp Neurol. 1994;343(1):1-16.

70. Puliti A, Rossi PI, Caridi G, et al. Albuminuria and glomerular damage in mice lacking the metabotropic glutamate receptor 1. Am J Pathol. 2011;178(3):1257-1269.

71. Neale BM, Lasky-Su J, Anney R, et al. Genome-wide association scan of attention deficit hyperactivity disorder. Am J Med Genet B Neuropsychiatr Genet. 2008;147B(8):1337-1344.

72. Lesch KP, Timmesfeld N, Renner TJ, et al. Molecular genetics of adult ADHD: converging evidence from genome-wide association and extended pedigree linkage studies. J Neural Transm. 2008;115(11): 1573-1585.

73. Romanos M, Freitag C, Jacob C, et al. Genome-wide linkage analysis of ADHD using high-density SNP arrays: novel loci at 5q13.1 and 14q12. Mol Psychiatry. 2008;13(5):522-530.
74. Franke B, Neale BM, Faraone SV. Genome-wide association studies in ADHD. Hum Genet. 2009;126(1):13-50.

75. Poelmans G, Pauls DL, Buitelaar JK, Franke B. Integrated genomewide association study findings: identification of a neurodevelopmental network for attention deficit hyperactivity disorder. Am J Psychiatry. 2011;168(4):365-377.

76. Ramocki MB, Zoghbi HY. Failure of neuronal homeostasis results in common neuropsychiatric phenotypes. Nature. 2008;455(7215): 912-918.

77. Hess EJ, Jinnah HA, Kozak CA, Wilson MC. Spontaneous locomotor hyperactivity in a mouse mutant with a deletion including the Snap gene on chromosome 2. J Neurosci. 1992;12(7):2865-2874.

78. Hess EJ, Collins KA, Wilson MC. Mouse model of hyperkinesis implicates SNAP-25 in behavioral regulation. J Neurosci. 1996;16(9): 3104-3111.

79. Sagvolden T. Behavioral validation of the spontaneously hypertensive rat (SHR) as an animal model of attention-deficit/hyperactivity disorder (AD/HD). Neurosci Biobehav Rev. 2000;24(1):31-39.

80. Sagvolden T, Johansen EB, Aase H, Russell VA. A dynamic developmental theory of attention-deficit/hyperactivity disorder (ADHD) predominantly hyperactive/impulsive and combined subtypes. Behav Brain Sci. 2005;28(3):397-419; discussion 419-468. 


\section{Supplementary material}

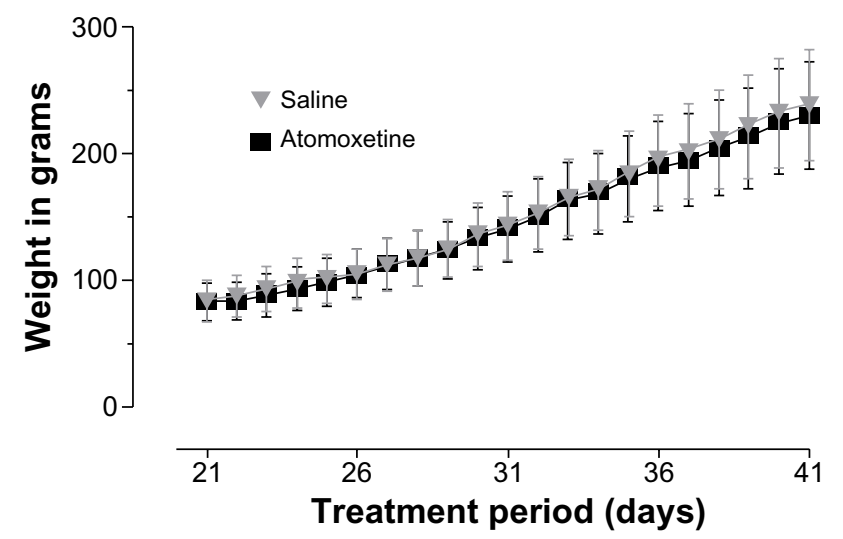

Figure SI Weight gain of male adolescent rats during treatment period. Notes: Sprague Dawley rats were treated once a day for 21 days (postnatal days $2 \mid-4 I)$ with atomoxetine hydrochloride $(3 \mathrm{mg} / \mathrm{kg}$ intraperitoneal [ip]) or saline $(0.9 \%$, ip). The treatment period is equivalent to the period of adolescence in humans. Rats were weighed once per day before treatment. The graph depicts mean total weight of saline and atomoxetine treated rats, \pm standard error of the mean; $n=7$.

\section{Publish your work in this journal}

Drug Design, Development and Therapy is an international, peerreviewed open-access journal that spans the spectrum of drug design and development through to clinical applications. Clinical outcomes, patient safety, and programs for the development and effective, safe, and sustained use of medicines are a feature of the journal, which has also been accepted for indexing on PubMed Central. The manuscript management system is completely online and includes a very quick and fair peer-review system, which is all easy to use. Visit http://www.dovepress.com/testimonials.php to read real quotes from published authors.

Submit your manuscript here: http://www.dovepress.com/drug-design-development-and-therapy-journal 